\title{
Bio-Remediation and Physicochemical Interaction of Experimentally Contaminated Soils in Uganda with Diesel
}

\author{
Denis Bbosa, Noble Banadda* and Peter Mulamba
}

Agricultural and Bio-systems Engineering Department, College of Agricultural and Environmental Sciences, Makerere University, P.O. Box 7062, Kampala, Uganda

\begin{abstract}
This study was conducted for a period of 4 weeks to monitor and evaluate the process of bio-stimulation and natural recovery rates in terms of bacteria and fungi communities to diesel contaminated soils. In this study, laboratory experiments were conducted to measure $\mathrm{pH}$, moisture content, Potassium (K), Phosphorous (P), Organic Nitrogen (ON), Organic Carbon (OC), Organic Matter (OM), fungi and bacteria cells before and after soils were intentionally contaminated with diesel. The results of this study showed that treatment level, $\mathrm{K}, \mathrm{P}$ and $\mathrm{pH}$ have a positive effect on the number of bacterial cells whereas moisture content, sand and clay particles impact negatively. A correlation coefficient of $\mathrm{R}^{2}=-0.93$ was obtained between time and OC, OM, ON while OC, OM, ON and bacteria showed an $\mathrm{R}^{2}=-0.58$. Three conclusions can be drawn based on this study. One, by week 4, bacterial cells counts had doubled. Two, by week 4 , bacterial counts numerically outnumbered fungal cells. Three, the increase in both bacterial and fungal cells was accompanied with a decrease in $\mathrm{OM}, \mathrm{OC}$ and $\mathrm{ON}$. This means that both bacterial and fungal cells had adapted by week 4.
\end{abstract}

Keywords: Pollution, Environment, Soil, Bio-stimulation, Diesel, pH, Fungi, Bacteria.

\section{INTRODUCTION}

Pollution of the environment by metals, metalloids and organic contaminants is an intractable globe problem with cleanup costs running into billions of dollars using current engineering technologies [1]. The availability of alternative, cheap and effective technologies is significantly improving the prospects of cleaning up contaminated sites among which is bioremediation and phytoremediation [1]. The problems associated with contaminated sites now assume increasing prominence in many countries [2].

Bioremediation is often less expensive than alternatives, can be done onsite and is environmentally benign [3]. Increasingly, biotechnology approaches to manage wastes from industrial, domestic and agricultural activities are needed. Advances in biotechnology have made bioremediation the most rapidly growing field of environmental restoration that can be exploited in cleaning up processes [4].

Accidental and deliberate crude or petroleum oil spills which have been and still continue to be a significant source of environmental pollution was the inspiration for this study because petroleum products contaminant poses a serious environmental problem due to contamination of air, water and soil and particularly soil contaminants typically alter plant metabolism, most commonly to reduce crop yields [5].

*Address correspondence to this author at the Agricultural and Bio-systems Engineering Department, College of Agricultural and Environmental Sciences, Makerere University, P.O. Box 7062, Kampala, Uganda;

Tel: +256 7740466 89; E-mail: banadda@agric.mak.ac.ug
Reginald [6] suggested that it is essential for nutrient supplementation and watering to be carried out during bioremediation works, more attention should be given to an effective tillage and pulverization system which maximizes the diffusion of oxygen within the soil profile. Aboaba [7] proposed that the rehabilitation of agricultural land polluted with crude petroleum at any contaminated place could be facilitated by inoculation with a selected culture of Pseudomonas putida. Okoh [8] postulated that the quest for a cheap source of energy coupled with the extensive rate of industrialization expands the frontiers of petroleum hydrocarbon exploration with its attendant negative consequence being the pollution of the environment. Several remediation alternatives have been in use for the restoration of polluted systems. Chikere [9] concluded that the soils may habour hydrocarbon degraders that have been exposed to hydrocarbons as a result of the increased multifarious activities of the oil industry.

Uganda has of recent discovered significant petroleum deposits in the western south part of the country. This discovery adds impetus to the relevance of this study. The aim of this study conducted for a period of 4 weeks was to monitor and evaluate the process of bio-stimulation and natural recovery rates in terms of bacteria and fungi communities to diesel contaminated soils.

\section{MATERIALS AND METHODS}

\subsection{Study Area}

The study area was Makerere University Agricultural Research Institute Kababyolo (MUARIK) where the experimental units were set and intentionally contaminated with 
Replication $3 \quad$ Replication $2 \quad$ Replication 1

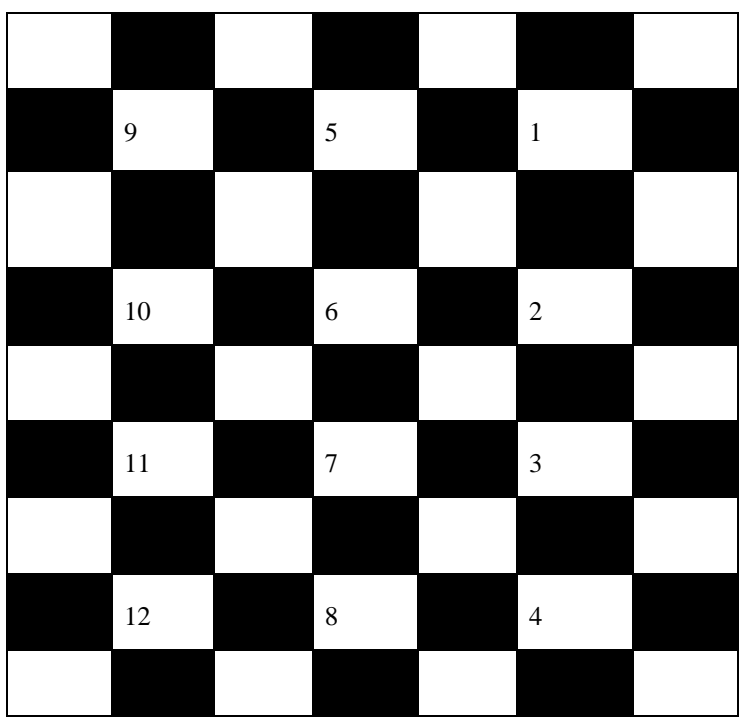

Key

Number Experimental areas of $0.5 \mathrm{~m} \times 05 \mathrm{~m}$

Excavated areas of $0.75 \mathrm{~m} \times 0.75 \mathrm{~m}$

Fig. (1). A scheme of experimental units.

diesel. MUARIK is located $19 \mathrm{~km}$ North of Kampala City, Uganda. The mean annual rainfall at MUARIK is $1160 \mathrm{~mm}$ distributed bimodal (March to June: September to November). The mean monthly temperature is $24.5^{\circ} \mathrm{C}$. The institute is located at $0^{0} 28^{1} \mathrm{~N}$ and $32^{0} 37^{1}$.

\subsection{Experimental Setup and Treatments}

The experimental plots of $0.5 \mathrm{~m} \times 0.5 \mathrm{~m}$ were setup in the field. An area of $4.5 \mathrm{~m} \times 5.5 \mathrm{~m}$ was allocated and measured off on ground using a tape measure. In a further step, $0.5 \mathrm{~m} \times 0.5 \mathrm{~m}$ experimental plots and $0.75 \mathrm{~m} \times 0.75 \mathrm{~m}$ plots were measured as pegs were driven into the ground using a hammer to separate the measured plots on ground and those to be excavated. The string was used to provide a guidance of straight lines. The $0.75 \mathrm{~m} \times 0.75 \mathrm{~m}$ plots were excavated to a depth of $1 \mathrm{~m}$ using a hoe so as to supply oxygen to the microorganism. To each experimental plot, it was surrounded by four holes. Prior to the fertilizer application, 500 $\mathrm{cm}^{3}$ (i.e. $0.5 \mathrm{~L}$ ) of diesel was sprinkled upon the earth in each of the cells including the control cell from a perforated can at the rate of $0.5 \mathrm{~L}$ of diesel per $0.25 \mathrm{~m}^{2}$ of soil hence the surface of the earth in each cell was completely covered with a thin layer of diesel. The objective was to simulate diesel spill. The cells were left undisturbed in the open air for three days. The NPK fertiliser treatments applied were $\mathrm{T}_{0}=0$ ton $/$ ha, $\mathrm{T}_{1}=60$ ton $/ \mathrm{ha}, \mathrm{T}_{2}=100$ ton $/ \mathrm{ha}, \mathrm{T}_{3}=140$ ton $/ \mathrm{ha}$. Three replications were performed. The levels were calculated basing on the factors affecting bio-remediation [10] and the simulated major spill condition. NPK was used as suggested by [8] and also being major microorganisms' requirements for bioremediation as per [10]. Fig. (1) depicts the experimental set-up.

\subsection{Sample Collection and Soil Analysis}

Soil samples were taken from a depth of 0-20 cm using a hand tool. In each treatment cell at least ten random spots were excavated, bulked together and put in well labeled polyethylene bags and immediately transferred to the laboratory for analysis. Soil physicochemical properties such as potassium, phosphorous, organic carbon, $\mathrm{pH}$, soil moisture, percentage of sand, silt and clay were monitored and measured. In addition, microbial counts of specifically, bacteria and fungi cells were measured during a period of 4 weeks. Particle-size analyses were obtained by the Bouyoucous hydrometer method, as modified by Day [11]. Organic carbon content was determined as per [12]. The organic nitrogen and moisture contents as well as the soil's $\mathrm{pH}$ value and were determined using methods adapted from [12-15]. The microbial analyses and bacterial counts were carried out following the procedure described by Harrigan and McCane [16] and Buchanan and Gibbons [17]. The obtained data was analyzed using descriptive statistics in Microsoft Excel. Data showed a normal distribution .The Coefficient of correlation $\mathrm{R}^{2}$ was used to correlate the measured data during the bioremediation process [18].

\subsection{Optimization Criterion}

The criterion to be maximized is the R-squared $\left(\mathrm{R}^{2}\right)$ value, which is often expressed in percent as shown in Equations (1). The values obtained from this criterion in this work reflect the percentage of output variation explained by the model.

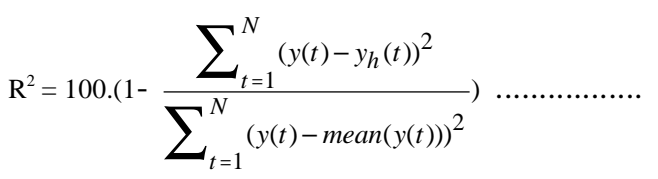

With $y(t)$ the measured output at discrete time $t$ and $y_{h}(t)$ the model output at discrete time $t$. Both performance indexes are used to evaluate the adequacy of the model.

\section{RESULTS AND DISCUSSION}

The results depicted in Fig. (2) show that the addition of diesel to the soil increased the soil $\mathrm{pH}$. The lowest and highest values being $5.40 \pm 0.017$ and $5.73 \pm 0.057$ for 100 ton NPK/ha and 0 ton NPK/ha at week zero and week 4 , respectively. This increase in soil $\mathrm{pH}$ may be attributed to the accumulation of exchangeable bases $(\mathrm{ca} 2+, \mathrm{K}+, \mathrm{Mg} 2+, \mathrm{Na}+)$ in the diesel contaminated soils. This finding is consistent with what is reported in literature namely, Benka Coker and Ekundayo [19] and Ekundayo and Obuekwe [20].

In Fig. (3), the lowest moisture of $13.87 \pm 0.64 \%$ was measured in the soil for the 60 ton NPK/ha treatment level while the highest was $24.30 \pm 0.68$ for 140 ton NPK/ha treatment. The increase in week 2 and week 4 could be attributed raining during the study period. Rowell [21] reported that in heavily polluted soils, water droplets adhere to the hydrophobic layer and this prevents the wetting of the soil aggregates.

As depicted in Fig. (4), potassium ranged from $312 \pm 9.93$ to $1372 \pm 308.65$. The increase in $\mathrm{K}$ concentration was due to 


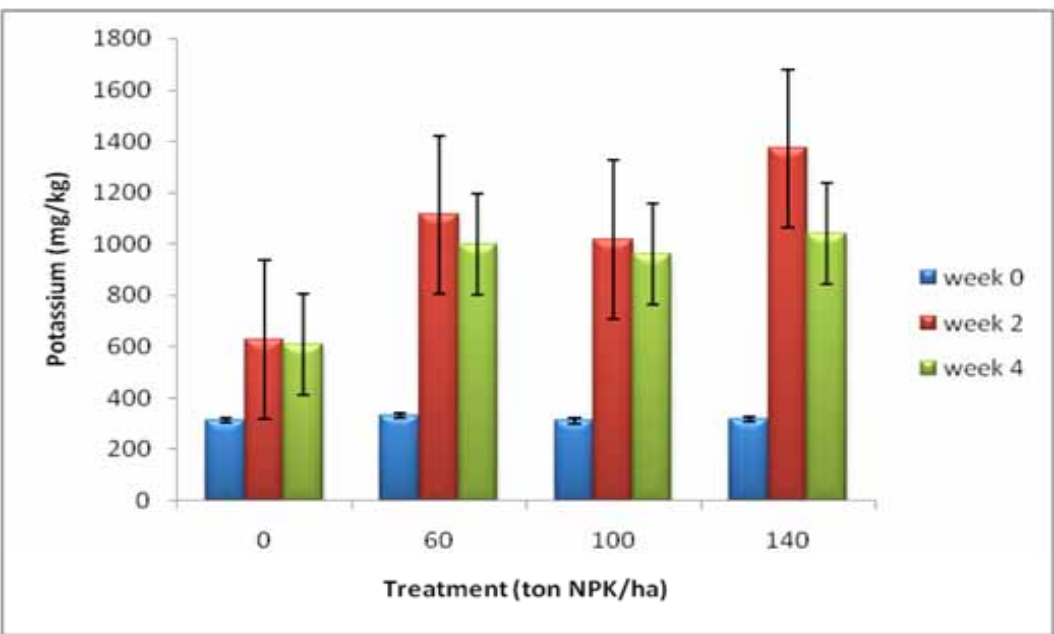

Fig. (2). Treatment Levels Against $\mathrm{pH}$.

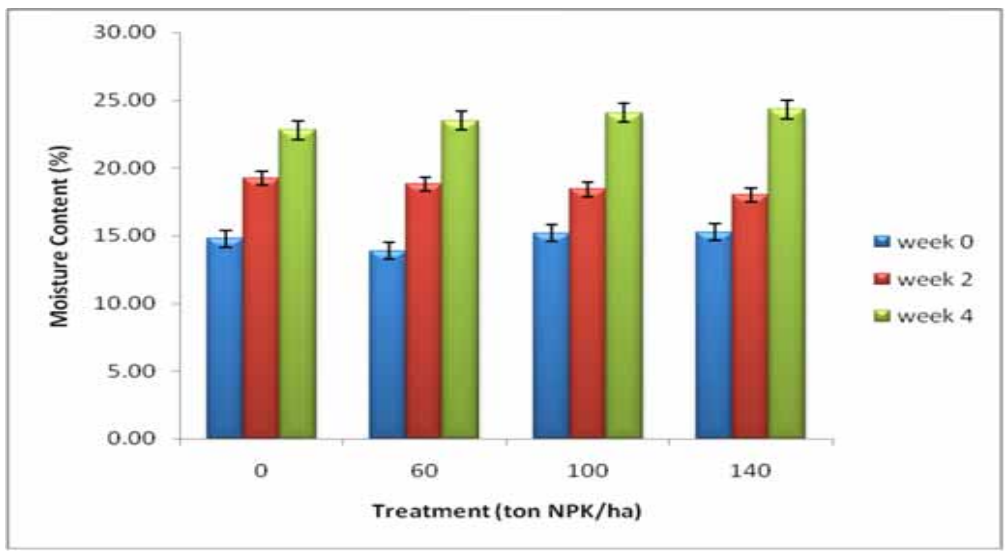

Fig. (3). Treatment levels against moisture content.



Fig. (4). Treatment levels against soil potassium.

NPK application in week 2. It is interesting to note that in week $4, \mathrm{~K}$ concentration dropped. This could be attributed to the fact that bacteria and fungi cells used $\mathrm{K}$ for growth, maintenance and energy.

In Fig. (5), phosphorous ranged from 52.65 \pm 3.65 to $63.60 \pm 2.80$. Utilization of $\mathrm{P}$ followed similar partners as $\mathrm{K}$ in Fig. (4). This finding in conformity with literature published by Katherine and Alan [22] and Isirimah [23] who noted that increasing $\mathrm{pH}$ increases weathering and mineralization rate. In a related study, Siddiqui and Adams [24] recorded increased $\mathrm{P}$ with increasing concentrations of diesel hydrocarbons for a definite period before registering a decline. 


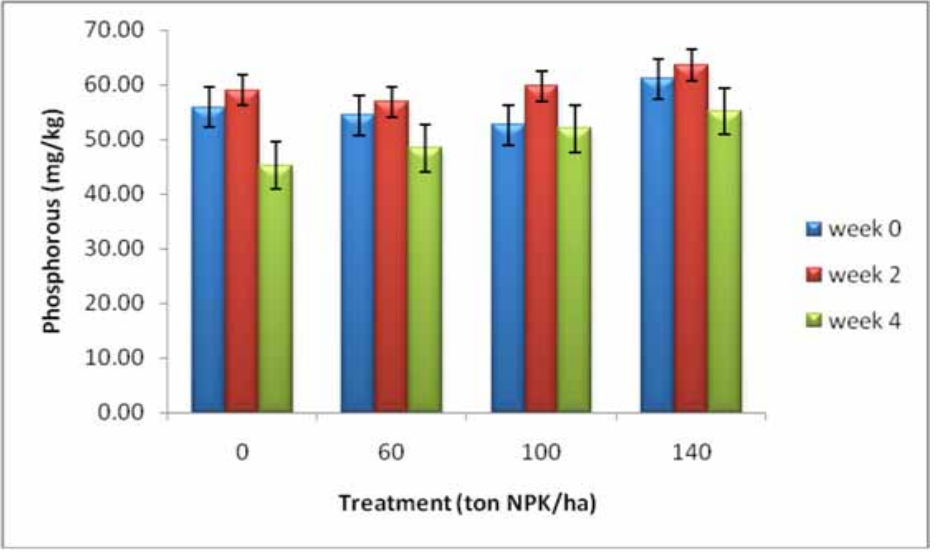

Fig. (5). Treatment levels against phosphorous.

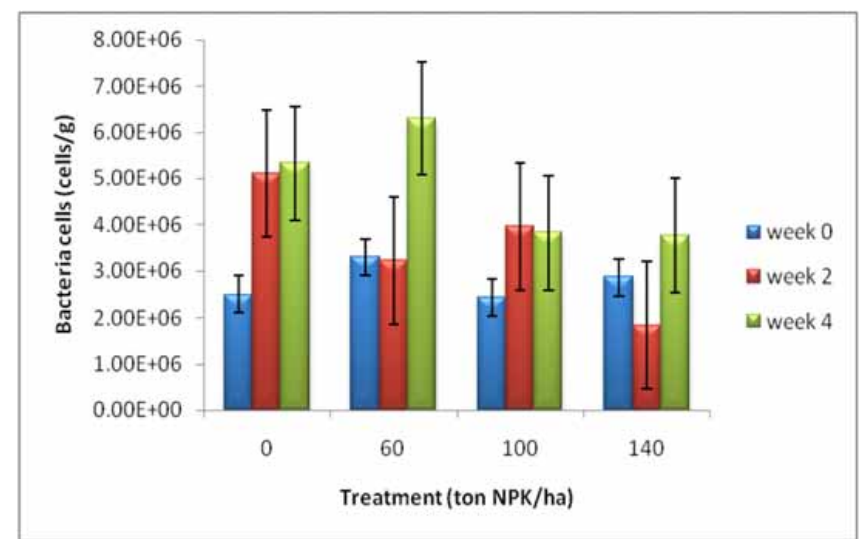

Fig. (6). Treatment levels against bacterial counts.

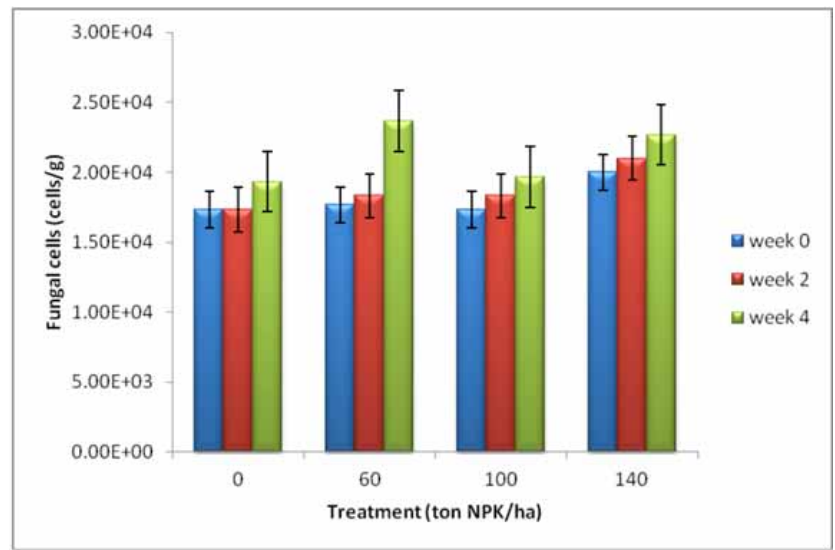

Fig. (7). Treatment levels against fungal counts.

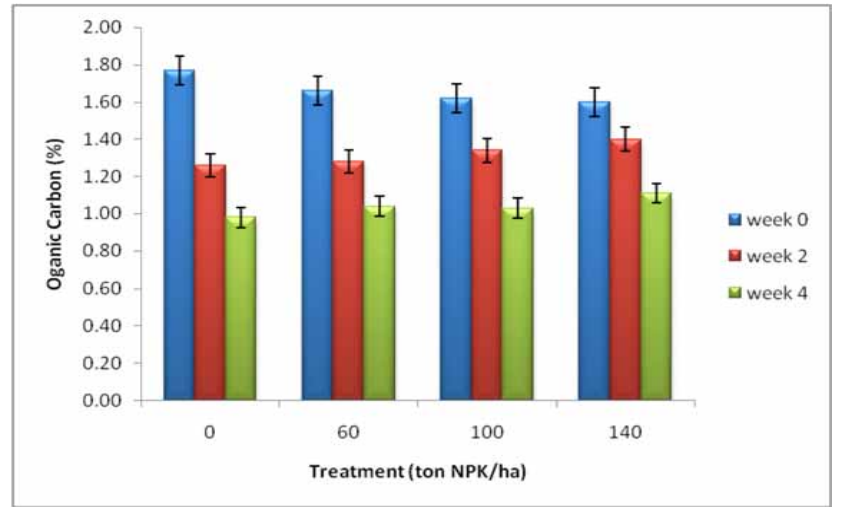

Fig. (8). Treatment levels against Organic Carbon. 


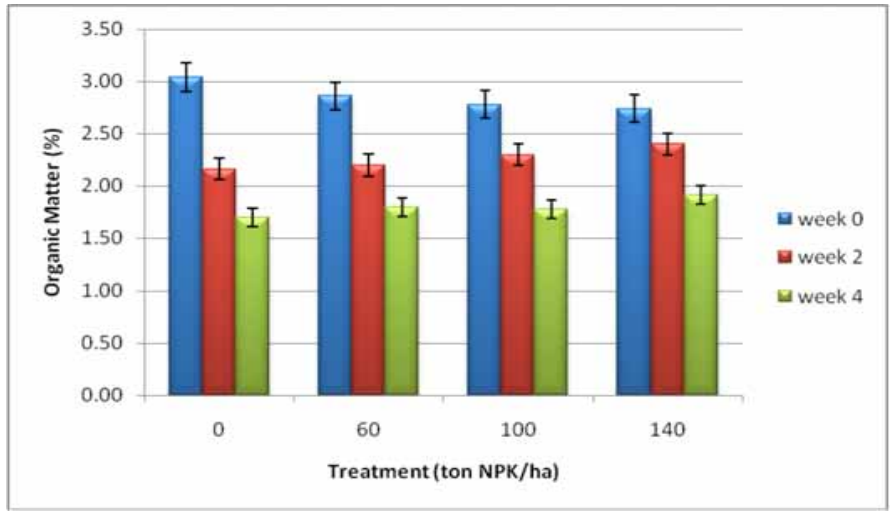

Fig. (9). Treatment levels against Organic Matter.

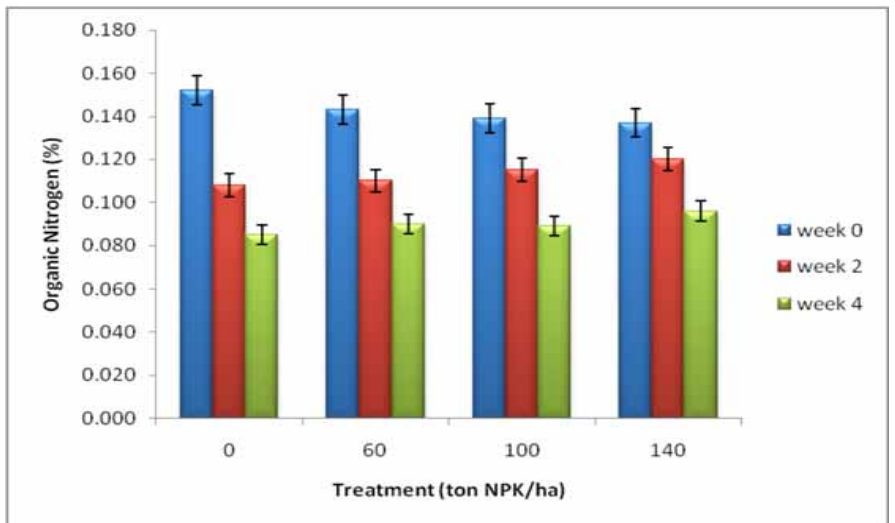

Fig. (10). Treatment levels against Organic Nitrogen.

It can be seen in Figure 6 that generally bacterial cells adapted to the diesel contaminated soils. The bacterial cells ranged from $1.83 \times 10^{6} \pm 1.37 \times 10^{6}$ to $6.30 \times 10^{6} \pm 1.23 \times 10^{6}$ cells/g. The correlation analysis, between the bacteria and remediation period, treatment levels, fungi and (Organic matter, carbon nitrogen) showed the relationships of $\mathrm{R}^{2}=$ $+0.58, \mathrm{R}^{2}=+0.40, \mathrm{R}^{2}=+0.06$ and $\left(\mathrm{R}^{2}=-0.58\right)$ at a $5 \%$ probability level, respectively.

A comparison of results in Figure 6 to those in Fig. (7) shows that few counts were obtained with fungal cells. The correlation obtained between time and fungi was $\mathrm{R}^{2}=+0.24$.

The results shown in Figs. (8-10) indicate that there was decrease in percent of available $\mathrm{OM}, \mathrm{ON}$ and $\mathrm{OC}$ from week 0 to week 4 . This is observation can be discussed in light with the results in Figs. (6 and 7). It can be noted that bacterial and fungal cells increased in number from week 0 to week 4 by utilizing these organic sources. However, BenkaCoker and Ekundayo [19] noted an increase in OC content of oil polluted soils in southern Nigeria.

\section{CONCLUSIONS}

Based on this study the following concluding remarks can be extracted:

1. By week 4 , bacterial cells counts had doubled. The bacterial cells ranged from $1.83 \times 10^{6} \pm 1.37 \times 10^{6}$ to $6.30 \times 10^{6} \pm 1.23 \times 10^{6}$ cells $/ \mathrm{g}$.

2. By week 4 , bacterial counts numerically outnumbered fungal cells.
3. By week 4, the increase in both bacterial and fungal cells was accompanied with a decrease in OM, OC and ON. This means that both bacterial and fungal cells had adapted by week 4 .

4. Potassium ranged from $312 \pm 9.93$ to $1372 \pm 308.65$ while Phosphorous ranged from $52.65 \pm 3.65$ to $63.60 \pm 2.80$

5. NPK application can be used in bioremediation as a cheap option to control diesel contamination of soils.

6. Further studies should be conducted to understand the relationships between water infiltration of diesel contaminated soils

7. Similar studies should be carried out for longer periods

\section{NOMENCLATURE}

$\begin{array}{lll}\% & = & \text { Percentage } \\ \mathrm{m} & = & \text { Metres } \\ \mathrm{L} & = & \text { Litre } \\ \mathrm{mm} & = & \text { millimetre } \\ \mathrm{cm} & = & \text { centimetre } \\ \text { ton/ha } & = & \text { tonne per hectare } \\ { }^{\circ} \mathrm{C} & = & \text { Degree celcious } \\ \mathrm{N} & = & \text { Nitrogen }\end{array}$




$\begin{array}{lll}\mathrm{P} & = & \text { Phosphorous } \\ \mathrm{K} & = & \text { Potassium }\end{array}$

\section{ACRONYMS}

$\begin{array}{lll}\text { MUARIK } & = & \begin{array}{l}\text { Makerere University Agricultural } \\ \text { Research Institute Kababyolo }\end{array} \\ \mathrm{HC} & = & \text { Hydrocarbon } \\ \mathrm{THC} & = & \text { Total Hydrocarbon Concentration } \\ \mathrm{R}^{2} & = & \text { Coefficient of correlation }\end{array}$

\section{CONFLICT OF INTEREST}

None declared.

\section{ACKNOWLEDGEMENTS}

The authors are very grateful to Inter-University Council of Eastern Africa through Lake Victoria Research (VicRes) for accepting to pay for the publication of this work. We also thank Bbosa Denis \& Miss Jane Nantongo for their cooperation.

\section{REFERENCES}

N. Linacre, N.W. Steven and J.S. Angle, "Incorporating Project Uncertainty in Novel Environmental Biotechnologies: Illustrated using phytoremediation", International Food Policy Research Institute, Environment and Production Technology Division, 2005.

[2] U.S. EPA, "Handbook on In Situ Treatment of Hazardous Waste Contaminated Soils", EPA/540/2-90/002, 2006.

[3] M. Dua, A. Singh, N. Sethunathan and A. K. Johri, "Biotechnology and bioremediation: successes and limitations", Appl. Microbiol. Biotechnol., vol. 59, pp.143-152, 2002.

[4] OFAB Open Forum on Agricultural Biotechnology in Africa, "Biotechnology and Bioremediation of Polluted Environments: Research and Development in Uganda", 2009.

[5] T. P. Kostecki and M. Behbehani, Assessment and Remediation of Oil Contaminated Soils, New Age International (P) Limited Publishers: New Delhi, 1999.

[6] R. Kogbara B, "Ranking agro-technical methods and environmental parameters in the biodegradation of petroleumcontaminated soils in Nigeria", Electron. J. Biotechnol., vol. 11, no. 1,2008 .

[7] O.A. Aboaba, O.O Aboaba, N.C. Nwachukwu, E.E Chukwu and, S.C.U Nwachukwu, "Evaluation of bioremediation of agricultural soils polluted with crude oil by planting beans seeds, Phaseolus Vulgaris", Nat. Sci., vol. 5, no. 4, pp. 53-60, 2007.
[8] A.I. Okoh, "Biodegradation alternative in the cleanup of petroleum hydrocarbon pollutants", Biotechnol. Mol. Biol. Rev., vol. 1, no. 2, pp. $38-50,2006$.

[9] C.B. Chikere, G.C. Okpokwasili and B.O. Chikere, "Bacterial diversity in a tropical crude oil-polluted soil undergoing bioremediation", Afr. J Biotechnol., vol. 8, no.11, pp. 2535-2540. 2009

[10] M. Vidali, "Bioremediation: an overview", Pure. Appl. Chem., vol. 73, no. 7, pp. 1163-1172, 2001.

[11] P.R. Day, "Particle fractionation and particle-size analysis", In: C.A. Black Ed., Methods of Soil Analysis part 1, Wisconsin, U.S.A: American Soc. of Agronomy Inc. Madison, 1965, pp. 545-567.

[12] D.W. Nelson and L.E. Sommers, "Total carbon, organic carbon and organic matter, In: A.L. Page et al. Ed. Methods of Soil Analysis, Part 2, $2^{\text {nd }}$ ed., Agronomy, vol. 9: 961-1010. Am. Soc. Agron., Inc. Madison, WI. 1996.

[13] R. B. Bradstreet, "The Kjeldahl Method for Organic Nitrogen", Academic Press Incorporated: New York, 1965.

[14] American Society for Testing and Materials, "Standard Test Method for Laboratory Determination of Water (Moisture) Content of Soil and Rock by Mass" 100 Barr Harbor Dr., West Conshohocken, PA 19428, D 2216-98, 1998.

[15] Geotechnical Engineering Bureau, "Geotechnical Test Method: Test Method For Determination Of pH Value of Water Or Soil by pH Meter", GTM-24, Revision \#2, 2007.

[16] P.M. Steubing, "Isolation of an unknown bacterium from soil", In: C.A. Goldman, Ed., Tested studies for laboratory teaching, Pages 81-114, vol. 14, Proceedings of the 14th Workshop/Conference of the Association for Biology Laboratory Education (ABLE), 1993.

[17] D.H. Bergey and G.J. Holt, Bergrey's Manual of Determinative Bacteriology, Williams and Wilkins Co.: Baltimore, USA, 1994.

[18] D.J. Finney, Statistical Methods in Biological Assay, $3^{\text {rd }}$ ed Charles Griffin: London, 1978.

[19] M.O. Benka-Coker and J.A. Ekundayo, "Effects of an oil spill on soil physicochemical properties of a spill site in the Niger Delta area of Nigeria", Environ. Monitor. Assess., vol. 36, pp. 93-104, 1995.

[20] E.O. Ekundayo and C.A. Obuekwe, "Effects of oil spill on soil physicochemical properties of a spill site in a typic paledult of Midwestern Nigeria", Environ. Monitor. Assess., vol. 22, pp.187196, 1997.

[21] M.J. Rowell, "The effect of crude-oil spills on soil: a review of the literature", Reclamation Agric Soil Oil Spills, Res., vol. 1, pp.27, 1977.

[22] J.K. Elliott, S.A. White, "effects of light, nitrogen, and phosphorus on red pine seedling growth and nutrient use efficiency", Forest Sci., vol. 40, no. 1, pp. 47-58, 1994

[23] A.O. Isirimah, A.A. Dickson and C. Igwe, Introductory Soil Chemistry and Biology, Osia Publishers Ltd.: Diobu, Port Harcourt, 2003

[24] S. Siddiqui and W. A. Adams, "The fate of diesel hydrocarbons in soils and their effect on the germination of perennial ryegrass", Environ. Toxicol., vol. 17, pp. 49-62, 2002.

(C) Bbosa et al.; Licensee Bentham Open.

This is an open access article licensed under the terms of the Creative Commons Attribution Non-Commercial License (http://creativecommons.org/licenses/by-nc/3.0/g) which permits unrestricted, non-commercial use, distribution and reproduction in any medium, provided the work is properly cited. 